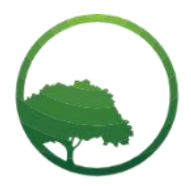

Research in Business \& Social Science

IJRBS VOL 10 NO 4 ISSN: 2147-4478

\title{
The analysis of patients' revisits intention factors in sub-urban hospital
}

\author{
Yuniarti $^{(a)}$ (iD) Anas Hidayat ${ }^{(b)}$ \\ (a) Magister Management Program, Faculty of Business and Economics, Universitas Islam Indonesia, Indonesia

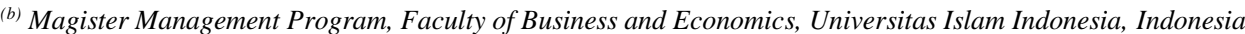

\author{
A RTICLE INFO \\ Article history: \\ Received 18 May 2021 \\ Received in rev. form 10 June 2021 \\ Accepted 12 June 2021 \\ Keywords: \\ Quality of medical services, quality of \\ non-medical services, satisfaction, \\ trustworthiness, revisit intention, sub- \\ urban hospital \\ JEL Classification: \\ I11, I15, M31
}

\begin{abstract}
A B S T R A C T
Revisit intention is a very important topic in a marketing context. However, previous literature is still rarely linked together with trust, satisfaction and two types of service, namely medical and non-medical with the hospital as the subject. Hospitals have the task of providing complete individual health services. This study aims to analyze the relationship between the quality of medical services and the quality of non-medical services on satisfaction, trust and revisit intention on the sub-urban hospitals. This research is a quantitative study using primary data from distributing questionnaires to 250 patients of the sub-urban hospitals. The data in this study were analyzed using the SEM (Structural Equation Model) method with AMOS 24 software. The results of this study indicate that the quality of medical services and the quality of non-medical services have a positive and significant effect on satisfaction. Meanwhile, patient satisfaction has a positive and significant effect on trust and revisit intention. However, trust was found to have a positive but insignificant effect on revisit intention. This research recommends several implications to the management of sub-urban hospitals. The managers of the sub-urban hospital are advised to pay more attention to and emphasize medical services, nonmedical services, and patient satisfaction because it has been empirically proven to increase Revisit Intention.
\end{abstract}

(C) 2021 by the authors. Licensee SSBFNET, Istanbul, Turkey. This article is an open access article distributed under the terms and conditions of the Creative Commons Attribution (CC BY) license (http://creativecommons.org/licenses/by/4.0/).

\section{Introduction}

Hospitals have the task of providing complete individual health services. Plenary health services are health services that include promotive, preventive, curative and rehabilitative health services. Based on data from the Directorate General of Health Services, the Indonesian Ministry of Health in 2019 the number of hospitals in Indonesia currently is 2,830 hospitals consisting of 1,016 government hospitals and 1,804 private hospitals. In 2020 the number of hospitals in Indonesia has increased to 2,925 hospitals. With so many hospitals spread across various regions, it is easy for people to get these health facilities. Hospitals in Kebumen Regency based on SIRS data (Hospital Information System) yankes.kemenkes.go.id as many as 11 hospitals consisting of 2 government hospitals and 9 private hospitals. This condition requires companies to create a competitive advantage in their business in order to be able to compete on an ongoing basis. Therefore, hospitals are required to pay attention to the quality of services offered to patients so that patients feel satisfaction with the quality offered (Rizkiawan, 2019). According to Tjiptono (2014), service quality is defined as a dynamic condition associated with products, services, people, processes, and environments that meet or exceed expectations.

Companies that want to develop and gain competitive advantage must be able to provide products in the form of quality goods or services and great service to their competitors' customers. Quality health services must be provided by all parts of the hospital. Service is a measure of how good the level of service that can be provided in accordance with customer expectations (Tjiptono, 2014). Therefore, the quality of service is very important and has an impact on patient satisfaction. Patient satisfaction is a very important thing to pay attention to, because it can describe the quality of service at the health service place. In this case, the author wants to

* Corresponding author. ORCID ID: 0000-0002-2879-4792

(C) 2021 by the authors. Hosting by SSBFNET. Peer review under responsibility of Center for Strategic Studies in Business and Finance.

https://doi.org/10.20525/ijrbs.v10i4.1232 
prove the success or failure of Sub-urban hospital in providing quality services to patients so as to produce satisfaction, foster trust and intention in patient repeat visits.

According to Fadhila \& Diansyah (2018), the level of patient satisfaction is determined by the quality of service desired by the patient, so that this can attract the public, to what extent is patient satisfaction with the quality of hospital services. Other studies have also stated that service convenience and satisfaction affect revisit intention (Shahijan, et al , 2018). This means that the higher the level of patient satisfaction, the higher the patient's confidence in the quality of hospital services. Patient satisfaction is an important thing to consider in building patient trust. Patients will feel satisfied if they get services that meet their expectations, both from officers and complete facilities on sub-urban hospital. If patients are satisfied, they will trust the services on sub-urban hospital, where they will recommend others to use the health facility when they need it.

Hospitals must minimize the occurrence of work mistakes made by medical and non-medical personnel during actions or treatments so that patients feel confident with the services they have received. Patient trust is a kind of emotional reflection for the business world of health clinics. It depends on the level of fulfillment of the expected product or service excellence, as well as the level of consistency of expectations and actual results. If the patient expects a certain level of service, and the service he feels is higher than he expected and continues to use the product or service, it can be said that the patient believes. Similarly, if the patient expects a certain level of service, and in fact the patient feels that the service he receives is consistent with his expectations, then the patient will be satisfied. On the other hand, if the quality of service received is lower than the expected service quality, then the patient is dissatisfied and distrusted (Fadhila \& Diansyah, 2018).

Previous research said that patients who are only satisfied with dental clinic services do not guarantee that patients become loyal and want to return to treatment. Patients must feel confident that the clinic or hospital service they receive is very good and suitable for them (self-confidence) will tend to be loyal and want to seek treatment again (Tanudjaya, 2014). Learning about how to build trusting relationships between doctors and patients is difficult and cannot be taught to us today, despite the use of such methods in anatomy or physiology (Hamelin, et al., 2012).

By providing quality services, it will create a good perception and can satisfy consumers to gain confidence. If patients do not get the services they expect, they are less likely to trust and will not visit the clinic again. Confidence is a valuable set for a company (Adinata \& Yasa, 2018), with the belief that the importance of revisiting will increase. Furthermore, Clara (2017) argues that trust has a significant effect on buying intention, while Aziz \& Hendrastyo's research (2019; Poon \& Koay, 2021) says that trust has no significant effect on buying intention. Therefore, the authors are intentioned in using this variable to compare the findings of previous studies.

Research related to the influence of service quality, trust and satisfaction on intention in hospital visits has also been analyzed by Rizkiawan (2019) and found that service quality, trust and satisfaction can affect the Revisit Intention. To further explore the quality of service, this study divides the types of service quality in hospitals into two, namely the quality of medical and non-medical services so that it can be known more deeply which service quality can affect patient satisfaction and Revisit Intention. Another novelty in this study is the analysis of the relationship between satisfaction and trust where most previous studies are still analyzing the relationship between trust and satisfaction. Based on the description above, it is necessary to do research on the factors that cause patients to have an intention in using health services again.

\section{Literature Review}

\section{Quality of Medical Services and Patient Satisfaction}

The quality of health services is one of the most important topics in the field of health services today. Improving and even maintaining the quality of care while reducing costs is a critical dilemma facing all health care administrators. The definition, measurement and improvement of quality in health care has become a very important issue. With pressure to increase access while limiting costs, competitive healthcare institutions strive to achieve their goals without allowing quality to deteriorate (Janavath \& Anand, 2016). Perception of the quality of medical or health services is an assessment of whether the service is most suitable / produces the best results that can be rationally accepted by the patient or the service provided by considering the doctor-patient relationship (Aliman \& Mohamad, 2013).

The quality of medical services has an important role in increasing patient satisfaction. The results of research conducted by Wididana (2017; Maulana, 2016; Jandavath \& Anand, 2016; Utari, 2013) concluded that the quality of medical services has a positive and significant effect on satisfaction. This means that the better the quality of service provided by the company, it will be able to increase customer satisfaction. However, Isa et al. (2019) stated different findings that service quality had no significant effect on satisfaction. However, research that proves the existence of a significant effect of service quality on satisfaction is more than the opposite finding. Therefore, based on the results of the discussion, the following research hypotheses are put forward:

H1: Service quality has a positive effect on customer satisfaction

\section{Quality of Non-Medical Services and Patient Satisfaction}


Hospital non-clinical services have very similar characteristics to most other services. Non-clinical services also have multidimensional aspects. Hospital non-clinical services are focused on multidimensional aspects of service management, such as; general administration and maintenance, ancillary services, support services and hospital value added services (Zubayer \& Hoque, 2019). Debajani \& Tathagata (2016) revealed that factors such as hospital atmosphere, physical facilities, location, hygienic care and visually appealing decorations had a significant effect on patient satisfaction. Amin, et al (2016) found that hospital facilities, medical equipment, and natural surroundings increased patient satisfaction. In terms of Healthscope design, hospitals need to understand patients' unmet consumption needs and how to meet their needs using a variety of services cape stimuli.

In addition to medical service satisfaction, patient satisfaction can also be increased through non-medical service satisfaction. The results of research conducted by Wididana (2017; Utari, 2013; Jandavath \& Anand, 2016; Debajani \& Tathagata, 2016 ; Zubayer \& Hoque , 2019 ; Amin, et al ., 2016 ; Priyadarshanie, et al ., 2017) concluded that non-clinical/non-medical services had an effect on satisfaction. However, another finding by Hutchinson (2009; Isa et al., 2019) found the opposite finding which states that there is no significant effect of non-medical service quality on patient satisfaction. Based on the results of the discussion, the research hypothesis is put forward as follows:

H2: The quality of non-medical services has a positive effect on satisfaction

\section{Patient Satisfaction and Trust}

Kotler \& Armstrong (2012) stated that consumer satisfaction depends on the assumption of the product's perceived performance in providing value in scores relative to consumer expectations. If the product's performance is much lower than consumer expectations, the buyer is dissatisfied. However, if the product performance matches expectations, consumers will feel very satisfied. Customer satisfaction can be significantly affected by friendliness to behavior that is friendly, welcoming, polite, etc. and the quality of service received is in accordance with customer expectations (Prawranata, et al, 2016). To create patient satisfaction, hospitals must create and manage systems to get more patients and the ability to retain patients so that when there are health problems the patient will return to the hospital (Rahmawati, 2018).

The performance of a hospital can be seen from the level of patient satisfaction. Patient satisfaction greatly determines the image of the hospital in the community and is a very important marketing instrument. The results of research conducted by Tanudjaya (2014; Miswanto and Angelia, 2018; Fadhila \& Diansyah, 2018; Wididana, 2017) show that satisfaction has a positive and significant effect on trust. Customers will trust the service company from experience when using the service whether it has met or exceeded their expectations. However, Permana et al. (2020) found contradictory findings which state that employee satisfaction has no significant effect on trust. Based on the results of the discussion, the research hypothesis is put forward:

\section{H3: Patient satisfaction has a positive effect on trust}

\section{Patient satisfaction and Revisit Intention}

Consumer satisfaction depends on the assumption that customer satisfaction performance can be seen from their behavior during post-purchase, consumers who are satisfied with the product / service offered will buy the product / service again from the same company and will repurchase the product / service when the need for the product / service. services appear in the future. Patients who receive good quality care will come back again if they need treatment, spreading positivity to friends and family (Tanudjaya, 2014). Satisfaction or dissatisfaction of consumers/customers is a response to the evaluation of the perceived discrepancy or disconfirmation between previous expectations and the actual performance of the product that is felt after use (Putri, 2015).

Employee satisfaction in addition to being able to have a significant influence on trust can also have an influence on patient repeat visits. Chahal \& Kumari (2010) explained that service quality leads to patient satisfaction and patient loyalty. The results of research conducted by Kessler \& Mylod (2011; Chahal and Kumari, 2010; Rizkiawan, 2019; Tanudjaya, 2014; Ismoyo, et al. 2017) concluded that satisfaction had a positive effect on revisit intention although there were contradictory findings by Hutchinson (2009; Permana et al. 2020) who found that satisfaction had no significant effect on intention in return visit. This can be interpreted that in general the more satisfied customers are, the intention to return will also increase. Based on the results of the discussion, the research hypothesis is put forward as follows:

H4: Patient satisfaction has a positive effect on Revisit Intention

\section{Trust and Revisit Intention}

Trust is the company's willingness to rely on business partners. Trust depends on a number of interpersonal and inter-organizational factors. Such as corporate competence, integrity, honesty and kindness (Kotler \& Keller, 2016). In the health or healthcare industry, patient satisfaction is an important component in addition to measuring the quality of carebut can also positively affect patient trust (Aliman \& Mohamad, 2013). It is important for companies to build customer trust in the products or services they offer, so that the level of customer trust is higher in the company and customer satisfaction is created (Darwin \& Kunto, 2014).

Trust is an important aspect in increasing Revisit Intention. The results of research conducted by Tanudjaya (2014; Saleem, et al. 2017; Rizkiawan, 2019) prove that trust has a positive effect on Revisit Intention. However, there are also contradictory findings by Poon \&Koay (2021; Isa et al., 2019; Napitupulu et al. 2021) who found that trust did not have a significant effect on the intention to 
revisit. Most of the previous researchers proved that there was a significant influence of trust on the Revisit Intention. This means that trust causes repurchase behavior in the future. Based on the results of the discussion, the research hypothesis is put forward as follows:

\section{H5: Trust has a positive effect on Revisit Intention}

\section{Research Framework}

This study aims to determine the effect of one variable on another, namely the variable quality of medical services (X1) and quality of non-medical services (X2) on patient satisfaction (Y1), consumer satisfaction (Y1) on trust (Y2) and Revisit Intention. (Y3), and confidence (Y2) in the revisit intention (Y3). Based on the theory and hypothesis development above, the research framework is as shown in the figure 1.

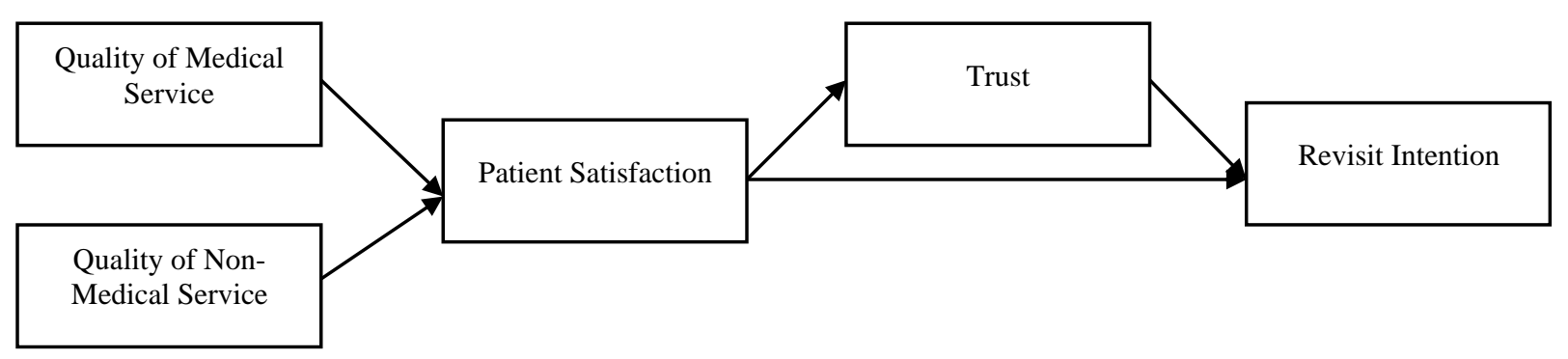

Figure 1: Research Framework

\section{Research and Methodology}

The population in this study were inpatients at sub-urban hospital. The sampling technique used in this study is a non-probability sampling technique. The non-probability sampling technique used in this research is purposive sampling, namely the sampling technique by selecting the sample desired by the researcher. Considerations in selecting samples are based on certain criteria, namely:

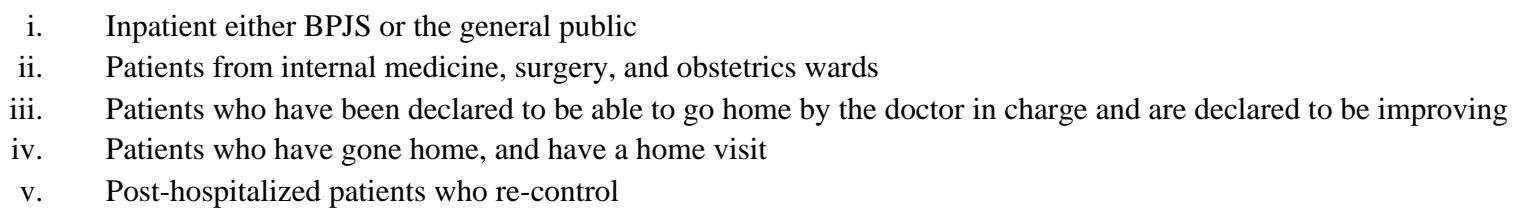

In measuring sample requirements in the Structural Equation Modeling (SEM) analysis method, this study uses the approach used by Hair (1988) regarding sample size. A good number of samples is in the range of 100-200 samples. However, further in Hair, et al (2010) revealed that the number of samples in the SEM approach was adjusted to the number of indicators used in the questionnaire, therefore the researchers used a comparison of 5-10 times the minimum number of respondents was $24 \times 7=168$. The samples taken in the study this is 250 respondents.

\section{Result and Discussion}

The analysis used to prove the hypothesis is the calculation of the Structural Equation Model (SEM) with AMOS 24 software. The model development in this study is based on the concept of data analysis. In general, this research model consists of 2 exogenous variables and 3 endogenous variables. The exogenous variables in this study are the quality of medical services (KM), the quality of non-medical services $(\mathrm{KN})$. The endogenous variables in this study were patient satisfaction (KP), trust (KR) and Revisit Intention (MK).

\section{Confirmatory Analysis}

Confirmatory analysis is used to test the concept that is built using several measurable indicators. In the confirmatory analysis, the first thing to look at is the loading factor value of each indicator. Loading factor can be used to measure construct validity where a questionnaire is said to be valid if the questionnaire is able to reveal something that is measured by the questionnaire. According to Hair et al. (2010) the minimum number of factor loading is 0.5 or ideally 0.7 . If there is a value that is still below 0.5 , it will be removed from the analysis.

Furthermore, the reliability test was carried out. The reliability coefficient ranges from $0-1$, so the higher the coefficient (close to the number 1), the more reliable the measuring instrument is. Construct reliability is good if the construct reliability value is $>0.7$ and the variance extracted value is $>0.5$ (Yamin \& Kurniawan, 2009). The results of the validity and reliability tests are shown in the table1. 
Table 1: Validity and Reliability Test

\begin{tabular}{|c|c|c|c|c|c|}
\hline Indicator & Standard Loading & Standard Loading ${ }^{2}$ & Measurement Error & CR & VE \\
\hline KM5 & 0,883 & 0,780 & 0,220 & 0,9 & 0,6 \\
\hline KM4 & 0,758 & 0,575 & 0,425 & & \\
\hline KM3 & 0,874 & 0,764 & 0,236 & & \\
\hline KM2 & 0,772 & 0,596 & 0,404 & & \\
\hline KM1 & 0,707 & 0,500 & 0,500 & & \\
\hline KN5 & 0,921 & 0,848 & 0,152 & 0,9 & 0,8 \\
\hline KN4 & 0,930 & 0,865 & 0,135 & & \\
\hline KN3 & 0,905 & 0,819 & 0,181 & & \\
\hline KN2 & 0,821 & 0,674 & 0,326 & & \\
\hline KN1 & 0,790 & 0,624 & 0,376 & & \\
\hline KP5 & 0,748 & 0,560 & 0,440 & 0,9 & 0,7 \\
\hline KP4 & 0,809 & 0,654 & 0,346 & & \\
\hline KP3 & 0,910 & 0,828 & 0,172 & & \\
\hline KP2 & 0,913 & 0,834 & 0,166 & & \\
\hline KP1 & 0,851 & 0,724 & 0,276 & & \\
\hline KR1 & 0,865 & 0,748 & 0,252 & 0,9 & 0,8 \\
\hline KR2 & 0,899 & 0,808 & 0,192 & & \\
\hline KR3 & 0,882 & 0,778 & 0,222 & & \\
\hline KR4 & 0,889 & 0,790 & 0,210 & & \\
\hline KR5 & 0,851 & 0,724 & 0,276 & & \\
\hline MK1 & 0,967 & 0,935 & 0,065 & 1,0 & 0,9 \\
\hline MK2 & 0,983 & 0,966 & 0,034 & & \\
\hline MK3 & 0,933 & 0,870 & 0,130 & & \\
\hline MK4 & 0,960 & 0,922 & 0,078 & & \\
\hline
\end{tabular}

From Table 1 it can be seen that all indicators in this study already have a loading factor value of more than 0.5. Construct reliability (construct reliability) all variables have shown 0.7. As for the variance extracted in this study, each variable also has a value of 0.5 . So it can be concluded that the questionnaire used for this research is valid and reliable.

Furthermore, the conformity test of the confirmatory model was tested using the Goodness of Fit Index. Hair et al. (1998) divided the GOFI (Goodness of Fit Index) criteria into 3 types of criteria, namely absolute fit indices, incremental fit indices and parsimony fit indices. Of the three types of GOFI there are 25 criteria in total, but according to Hair et al. (2010) the SEM-Amos analysis does not require that all criteria be met, 4-5 criteria are sufficient as long as there are criteria that represent the three types of GOFI criteria. In this study, several criteria were taken from each type of GOFI, namely Chi-square, probability, RMSEA and GFI representing absolute fit indices, CFI and TLI representing incremental fit indices then PGFI and PNFI representing parsimony fit indices.

Table 2: First GOF Test

\begin{tabular}{lllll}
\hline Fit Index & Goodness of Fit & Criteria & Cut-off value & Fit \\
\hline Absolute Fit & Chi-square & Kecil & 840,966 & Not Fit \\
\cline { 2 - 4 } & Probability & $\geq 0.05$ & 0,000 & Not Fit \\
\cline { 2 - 4 } & RMSEA & $\leq 0.08$ & 0,100 & Not Fit \\
\cline { 2 - 4 } Incremental Fit & GFI & $\geq 0.90$ & 0,770 & Not Fit \\
\cline { 2 - 4 } & TLI & $\geq 0.90$ & 0,920 & Fit \\
\hline
\end{tabular}




\begin{tabular}{lllll}
\hline Parsimony Fit & PGFI & $\geq 0.60$ & 0,621 & Fit \\
\cline { 2 - 5 } & PNFI & $\geq 0.60$ & 0,782 & Fit \\
\hline
\end{tabular}

From the results of the goodness of fit test in table 2, it can be seen that there are still 4 criteria that are not fit. Therefore, to increase the GOF value, it is necessary to modify the model that refers to the modification index table by providing a covariance relationship or eliminating indicators that have a high MI (Modification Index) value. In the model modification process, there are several indicators that must be eliminated because they have high MI (Modification Index) values, namely KM2, KM3, KN1, KN2, KP4, KR5 and MK2.

After modifying the results, it shows that the Goddness of Fit value has met all the criteria, although one criterion is still marginal fit, but according to Hair et al. (2010) the value of marginal fit can still be tolerated so that the model in this study can be said to be Fit as shown in the table3.

Table 3: Final GOF Test

\begin{tabular}{lllll}
\hline Fit Index & Goodness of Fit & Criteria & Cut-off value & Fit \\
\hline \multirow{2}{*}{ Absolute Fit } & Chi-square & Kecil & 114,643 & Fit \\
\cline { 2 - 5 } & Probability & $\geq 0.05$ & 0,063 & Fit \\
\cline { 2 - 5 } & RMSEA & $\leq 0.08$ & 0,031 & Fit \\
\cline { 2 - 5 } & GFI & $\geq 0.90$ & 0,951 & Fit \\
\hline Incremental Fit & CFI & $\geq 0.90$ & 0,996 & Fit \\
\cline { 2 - 5 } & TLI & $\geq 0.90$ & 0,994 & Fit \\
\hline Parsimony Fit & PGFI & $\geq 0.60$ & 0,578 & Marginal Fit \\
\hline
\end{tabular}

\section{Hypothesis Test}

The next analysis is the full model Structural Equation Model (SEM) analysis to test the hypotheses developed in this study. The results of the regression weight test in this study are as shown in Figure 2 and table 4.

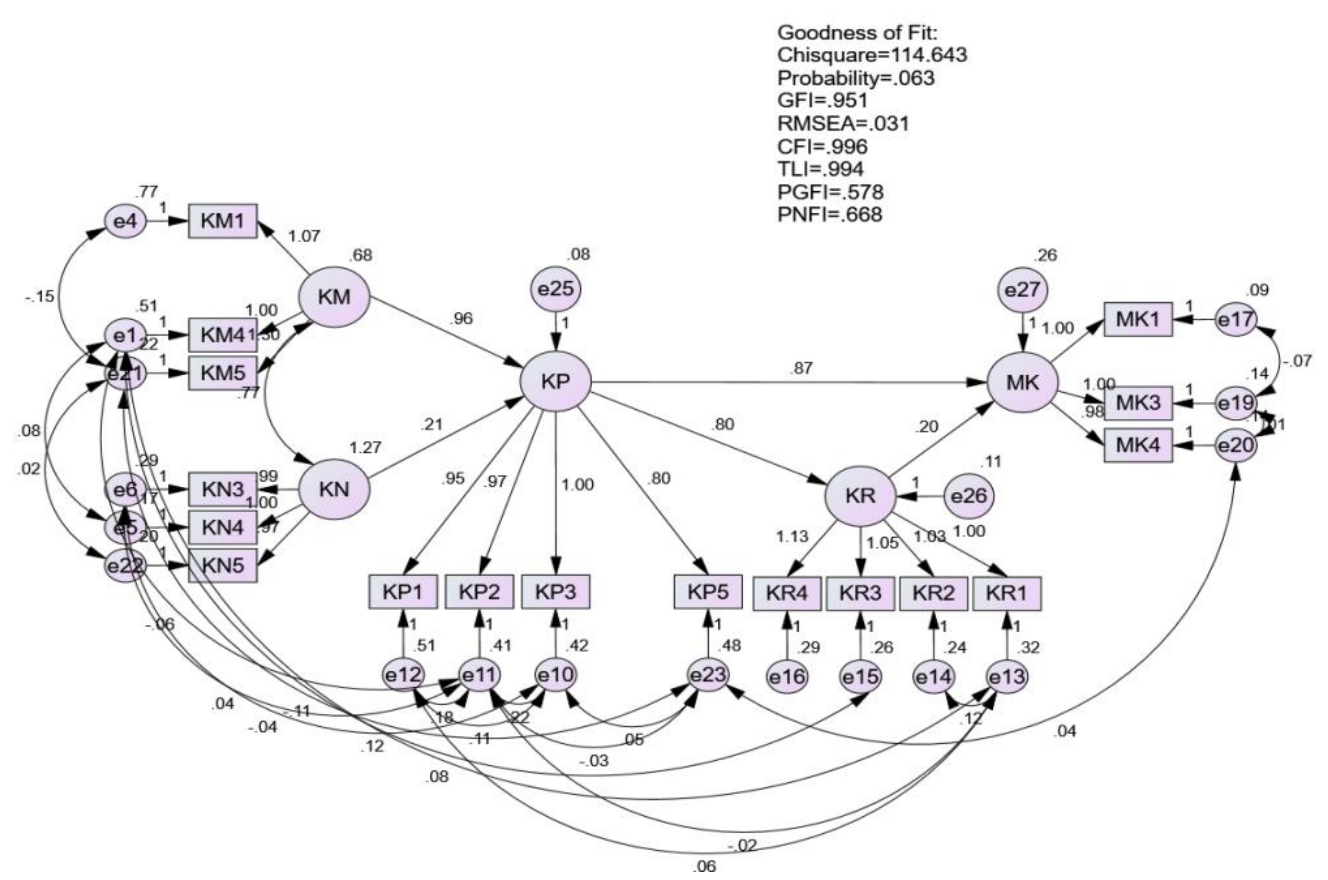

Figure 2: Final Model After Modification

Table 4: Regression Weight

\begin{tabular}{|c|c|c|c|c|c|c|c|}
\hline & & & Estimate & S.E. & C.R. & $\mathbf{P}$ & Result \\
\hline KP & $<---$ & $\mathrm{KM}$ & .962 & .113 & 8.520 & $* * *$ & Significant \\
\hline KP & $<---$ & $\mathrm{KN}$ & .213 & .070 & 3.056 & .002 & Significant \\
\hline KR & $<--$ & $\mathrm{KP}$ & .800 & .052 & 15.286 & $* * *$ & Significant \\
\hline
\end{tabular}




\begin{tabular}{|c|c|c|c|c|c|c|c|}
\hline MK & $<--$ & KP & .875 & .151 & 5.805 & $* * *$ & Significant \\
\hline MK & $<--$ & KR & .204 & .169 & 1.206 & .228 & Not Significant \\
\hline
\end{tabular}

The results of hypothesis testing can be seen by looking at the Critical Ratio (CR) value and the probability $(\mathrm{P})$ value from the results of data processing. The direction of the relationship between variables can be seen from the estimate value, if the estimate value is positive then the relationship between the variables is positive, whereas if the estimate value is negative, the relationship is negative. Furthermore, if the test results show a CR value above 1.96 and a probability value $(\mathrm{P})$ below $0.05 / 5 \%$, the relationship between exogenous and endogenous variables is significant. In detail, the research hypothesis testing will be discussed in stages according to the proposed hypothesis. The results of the analysis in Table 4 show that:

i. The quality of medical services (KM) has a positive and significant effect on patient satisfaction (KP). This result is evidenced by a positive estimate value, a t-statistic value above 1.96 and a P-Value value below 0.05 .

ii. The quality of non-medical services $(\mathrm{KN})$ has a positive and significant effect on patient satisfaction (KP). This result is evidenced by a positive estimate value, a t-statistic value above 1.96 and a P-Value value below 0.05 .

iii. Patient satisfaction (KP) has a positive and significant effect on trust (KR). This result is evidenced by a positive estimate value, a t-statistic value above 1.96 and a P-Value value below 0.05 .

iv. Patient satisfaction (KP) has a positive and significant effect on Revisit Intention (MK). This result is evidenced by a positive estimate value, a t-statistic value above 1.96 and a P-Value value below 0.05 .

v. Trust (KR) has a positive and insignificant effect on Revisit Intention (MK). These results are evidenced by a positive estimate value, a t-statistic value below 1.96 and a P-Value value above 0.05 .

\section{Discussion}

This study analyzed 5 variables related to marketing in hospitals, namely the influence of medical service quality (KM), non-medical service quality (KN), patient satisfaction (KP), trust (KR) and Revisit Intention (MK). Of the five variables, it was developed based on theory and previous research into 5 hypotheses which were analyzed in this study. Of the 5 hypotheses analyzed, it was found that the first, second, third and fourth hypotheses were supported and the fifth hypothesis was not supported.

The first hypothesis in this study is that the quality of medical services has a positive and significant effect on patient satisfaction. The results of the analysis in this study support the first hypothesis so that it is proven that there is a positive and significant influence between the quality of medical services on patient satisfaction. These results are supported by several previous studies including Wididana (2017; Maulana, 2016; Jandavath \& Anand, 2016; Utari, 2013; Rizkiawan, 2019) which also stated that there was an effect of the quality of medical services on patient satisfaction.

The findings of the first hypothesis analysis in this study indicate that the quality of medical services has an important role in increasing patient satisfaction on sub urban hospital. The better the quality of medical services, the better the patient satisfaction. Therefore, the management of sub-urban hospital should pay attention to and develop the quality of medical services in several forms, namely medical equipment, timeliness of service, speed and dexterity of service, guaranteed doctor expertise and sympathetic attitude from health workers.

However, there are findings that give contradictory results, namely by Isa et al. (2019) which states that service quality has no significant effect on satisfaction. However, research that proves the existence of a significant effect of service quality on satisfaction is more than the opposite finding. The findings of this study re-emphasize the importance of medical service quality in improving patient satisfaction.

The second hypothesis in this study is that the quality of non-medical services has a significant effect on patient satisfaction on Indonesian sub urban hospital. The results of the analysis in this study support the second hypothesis which states that there is a positive and significant influence on the quality of non-medical services on patient satisfaction on sub-urban hospital. These findings are supported by several previous studies by Wididana (2017; Utari, 2013; Jandavath \& Anand, 2016; Debajani \& Tathagata, 2016; Zubayer \& Hoque, 2019; Amin, et al.,2016; Priyadarshanie, et al., 2017; Rizkiawan, 2019).

The findings in this study indicate that in addition to the quality of medical services, sub-urban hospital must also pay attention to and develop the quality of non-medical services because the better the quality of non-medical services, the better the patient satisfaction. The quality of non-medical services that need to be improved by sub-urban hospital includes cleanliness and tidiness, operational timeliness, professional administration that is able to respond to patient needs, has sufficient information and knowledge to answer patient questions and is able to handle patients with care and patience.

On the other hand, previous research does not fully support the results of this study. Hutchinson (2009; Isa et al., 2019) found the opposite finding which states that there is no significant effect of non-medical service quality on patient satisfaction. However, most previous studies support the results of this study, namely the significant influence of non-medical services on patient satisfaction.

The third hypothesis in this study is that patient satisfaction has a significant effect on trust. The results of the analysis in this study support the third hypothesis and state that there is a positive and significant effect of patient satisfaction on trust on sub-urban hospital. These findings are supported by several previous studies, namely Tanudjaya (2014; Miswanto dan Angelia, 2018; Fadhila \& 
Diansyah, 2018; Wididana, 2017; Rizkiawan, 2019) so that it is increasingly proven that patient satisfaction has an important role in increasing trust.

The results of the third hypothesis analysis prove that the better the patient's satisfaction, the better the patient's trust on sub-urban hospital. In an effort to increase patient satisfaction, the management of Sub-urban hospital needs to develop several aspects, namely improving the performance of hospital services, providing fast and satisfactory responses to patient complaints, serving patients fairly and optimizing the delivery of information and the physical condition of the hospital.

However, the results of this study also contradict other findings by Permana et al. (2020) which states that employee satisfaction has no significant effect on trust. The results of Permana et al. (2020) showed that in general satisfaction is not an absolute determinant of trust but in different contexts and subjects it may be that satisfaction does not have a significant effect on trust. However, on average, previous research states that satisfaction is able to create trust.

The fourth hypothesis in this study is that employee satisfaction can have a significant effect on the Revisit Intention on sub-urban hospital. The results of the analysis in this study support the fourth hypothesis so that it is proven in this study that there is a positive and significant effect of employee satisfaction on the Revisit Intention on sub-urban hospital. These results are also supported by several previous studies by Kessler \& Mylod (2011; Chahal \& Kumari, 2010; Rizkiawan, 2019; Tanudjaya, 2014; Ismoyo, et al. 2017; Rizkiawan, 2019).

From the results of the fourth hypothesis analysis, it is known that if patient satisfaction on sub-urban hospital increase, the Revisit Intention will also increase. In an effort to increase patient satisfaction, the management of sub-urban hospital needs to develop several aspects, namely improving the performance of hospital services, providing fast and satisfactory responses to patient complaints, serving patients fairly and optimizing the delivery of information and the physical condition of the hospital.

The existence of the effect of patient satisfaction on intention in revisiting is contrary to research by Hutchinson (2009; Ha \& Kitchen, 2020) which found that satisfaction had no significant effect on Revisit Intention. However, the average previous research supports a significant influence between the two variables. Therefore, this proves that employee satisfaction should be emphasized by the hospital in order to increase the Revisit Intention.

The fifth hypothesis in this study is that trust has a significant effect on the Revisit Intention on sub-urban hospital. The results of the analysis in this study do not support the fifth hypothesis with the finding that trust has no significant effect on the Revisit Intention on sub-urban hospital. These results contradict several previous studies by Tanudjaya (2014; Saleem, et al. 2017; Rizkiawan, 2019) but supported by the findings by Poon \& Koay (2021; Isa et al, 2019; Arshad et al. 2016; Aziz \& Hendrastyo, 2019) which found that trust did not have a significant effect on revisit intention.

The results of the analysis of the fifth hypothesis in this study do not support the hypothesis, which means that trust is not a factor that can significantly increase repeat visits. From these results it can be concluded that sub-urban hospital should pay more attention to patient satisfaction than patient trust because patient satisfaction has more influence in increasing Revisit Intention. The absence of a significant effect of trust can be caused by several things, such as the average economic condition of patients who are middle to lower class making satisfaction and price the main factors in Revisit Intention.

Trust can be increased through several aspects including good and correct service, services that do not violate the rules, the ability to do work according to standards, provide services according to patient expectations and be able to provide appropriate information according to patient needs. The Revisit Intention can be indicated by several aspects, namely the desire to use the services for the next opportunity, provide recommendations to others and not move to another hospital.

From the results of hypothesis testing in this study, it is known that patient satisfaction can be significantly increased by efforts to improve medical and non-medical services provided to patients. Patient satisfaction itself can also have a significant effect on patient confidence and Revisit Intention, but trust is not able to significantly affect Revisit Intention. Therefore, several things that must be improved by sub-urban hospital are medical services, non-medical services and patient satisfaction.

\section{Implication}

From the results of the analysis in this study, the author recommends several implications of the findings to the management of suburban hospital. The managers of sub-urban hospital are advised to pay more attention to and emphasize medical services, non-medical services and patient satisfaction because it has been empirically proven to increase revisit Intention.

The manager of sub-urban hospital should also pay attention that with good service according to the standards determined by the law regarding hospital services, patient satisfaction will be created, patient satisfaction will have an impact on trust in the hospital and intention in recommending and revisiting on sub-urban hospital

\section{Conclusion}

This study analyzed 5 (five) variables related to marketing in hospitals, namely the influence of medical service quality (KM), quality of non-medical services (KN), patient satisfaction (KP), trust (KR) and Revisit Intention (MK). Of the five variables, it was developed based on the theory and previous research into 5 hypotheses which were analyzed in this study. Of the 5 hypotheses analyzed, it was 
found that the first, second, third and fourth hypotheses were supported and the fifth hypothesis was not supported. From the result, can be known that patient satisfaction can be significantly increased by efforts to improve medical and non-medical services provided to patients. Patient satisfaction itself can also have a significant effect on patient confidence and Revisit Intention, but trust is not able to significantly affect Revisit Intention. Therefore, several things that must be improved by sub-urban hospital are medical services, non-medical services and patient satisfaction.

\section{References}

Adinata, K.J., \& Yasa, N.N.K. (2018). Pengaruh Kepercayaan, Persepsi Harga, dan Sikap Terhadap Niat Beli Kembali Di Situs Lazada. E-Jurnal Manaj (Univ. Udayana), 7, 4153

Aliman, N.K., \& Mohamad, W.N. (2013). Perceptions of service quality and behavioral intentions: a mediation effect of patient satisfaction in privatecare in Malaysia. International Journal of Marketing Studies, 5(4), 1529.

Amin, S. H. M., Wahid, S. D. M., \& Ismail, M. (2016). Observing the natural dimension of hospital servicescape on patient satisfaction. Procedia Economics and Finance, 37, 58-64.

Arshad, T., Zahra, R., \&Draz, U. (2016). Impact of customer satisfaction on image, trust, loyalty and the customer switching behavior in conventional and Islamic banking: evidence from Pakistan. American Journal of Business and Society, 1(3), 154-165.

Aziz, N. \& Hendrastyo, Vito. (2019). Pengaruh Kualitas Layanan, Kepercayaan dan Promosi Terhadap Minat Nasabah Menabung Pada Bank Syariah Cabang Ulak Karang Kota Padang. Jurnal Pundi, 3(3), 227-234.

Chahal \& Kumari, (2010). Development of multi-dimensional scale for health care service quality (HCSQ) in Indian context.Journal of Indian Business Research, 2(4), 230 - 255

Clara, A. (2017). Analisis pengaruh kualitas online Word-Of-Mouth dan keamanan terhadap minat beli dengan kepercayaan sebagai variabel intervening pada pembelian produk fashion di situs zalora Indonesia di semarang. Diponegoro J. Manag, 6, 1-11

Darwin, S \& Kunto,Y.,S. (2014). Analisis pengaruh kualitas terhadap loyalitas pelanggan dengan kepuasan dan kepercayaan pelanggan sebagai variabel intervening pada asuransi jiwa manulife Indonesia-Surabaya.JurnalStrategiPemasaran, 2(1)

Debajani, S.\& Tathagata, G., (2016). Health scape role to wards customer satisfaction in private healthcare. International journal of health care quality assurance, 29(6), 600-613.

Fadhila, N. A., \& Diansyah. (2018). Pengaruh kualitas pelayanan dan kepercayaan terhadap loyalitas dengan kepuasan pasien sebagai variabel intervening di klinik syifa medical center. Media Studi Ekonomi, 21 (1).

Ha, H. Y., \& Kitchen, P. J. (2020). Positive crossover loyalty shifts or negative temporal changes? The evolution of shopping mechanism in the $\mathrm{O} 2 \mathrm{O}$ era. European Journal of Marketing, 54(6), 1384-1405.

Hamelin, N. D., Nikolis, A., Armano, J., Harris, P. G., \& Brutus, J. P. (2012). Evaluation of factors influencing confidence and trust in the patient-physician relationship: A survey of patient in a hand clinic. Chirurgie de la Main, 31(2), 83-90.

Hair, J. F. Jr., Black, W. C., Babin, B. J., \& Anderson, R. E., (2010), Multivariate Data Analysis, 7th Edition, Person Prentice Hall, Essex, UK.

Hair, J.F., Jr., et.al. (1998). Multivariate Data Analysis 5th ed. Englewood Cliffs, NJ: Prentice HallInt'l.

Hutchinson, J., Lai, F., \& Wang, Y. (2009). Understanding the relationships of quality, value, equity, satisfaction, \& behavioral intentions among golf travelers. Tourism management, 30(2), 298-308

Isa, S. M., Lim, G. S. S., \& Chin, P. N. (2019). Patients' intent to revisit with trust as the mediating role: lessons from Penang Malaysia. International Journal of Pharmaceutical \& Healthcare Marketing, 13(2), 140-159

Ismoyo., Suwandi. \& Sajiwo. (2017). Service Quality Perception's Effecton Customer Satisfaction and Repurchase Intention. European Business \& Management, 3(3), 37-46

Jandavath, R. K. N., \& Byram, A. (2016). Healthcare service quality effect on patient satisfaction and behavioural intentions in corporate hospitals in India. International Journal of Pharmaceutical and Healthcare Marketing, 10(1), 48-47.

Kessler, D. P., \& Mylod, D. (2011), Does patient satisfaction affect patient loyalty?, International Journal of Health Care Quality Assurance, 24 (4), 266-273

Kotler, Philip\& Armstrong, Gary. (2012). Prinsip-Prinsip Pemasaran. Edisi 12. jilid 2. Jakarta: Erlangga

Kotler, P., \& Keller, K. L. (2016). Marketing Managemen, 15th Edition, Pearson Education, Inc.

Maulana, Z. (2016). Pengaruh kualitas pelayanan medis, paramedis dan penunjang medis terhadap kepuasan pasien rawat inap di Rumah Sakit Harapan Bunda Banda Aceh. Jurnal Manjemen dan Keuangan, 5(1).

Miswanto \& Angelia Y.R. (2018). The Influence of Customer Satisfaction on Trust, Word of Mouth, and Repurchase Intention Case for Consumer of Souvenir Stores in Yogyakarta. ICEBM, 308-313.

Napitupulu, R., Sihombing, N., Napitupulu, B., \& Pardede, E. (2021). Customer satisfaction and trust interaction model. Management Science Letters, 11(4), 1101-1110.

Poon, W. C., \& Koay, K. Y. (2021). Hong Kong protests \& tourism: Modelling tourist trust on revisit intention. Journal of Vacation Marketing, 27 (2), 217-234.

Permana, I., Putra, K., Hudayah, S., \&Achmad, G. N. (2020). The effect of cv and customer trust on satisfaction and customer loyalty PT.SGI Samarinda Seberang. International Journal of Economics, Business and Accounting Research (IJEBAR), ,4(2), 151160

Prawiranata, A., Edy, Y., dan Andriani, K. (2016). Pengaruh Keramahtamahan Dan Kualitas Pelayanan Terhadap Kepuasan Pelanggan. Jurnal Administrasi Bisnis,32(1), 114-120. 
Putri, M. P. (2015). Pengaruh Kualitas Jasa Terhadap Kepuasan Pengunjung Objek Wisata Gua Pindul. Jurnal Tata Kelola Seni, $1(2), 68-81$

Rahmawati, K. N. (2018). Pengaruh Kualitas Layanan Medis, Kepercayaan Dan Kepuasan Terhadap Loyalitas Pasien Rawat Inap Rumah Sakit Pku Muhammadiyah Kebumen (Master'sthesis, Universitas Islam Indonesia).

Rizkiawan, I, K. (2019). Pengaruh kualitas pelayanan dan kepercayaan terhadap minat kunjung ulang dengan mediasi kepuasan pasien pada Rumah Sakit Amal Sehat Wonogiri. Doctoral dissertation, Universitas Muhammadiyah Surakarta.

Saleem., Mazhar., \& Naheed. (2017). Impact of service quality and trust on repurchase intentions - the case of Pakistan airline industry. Asia Pacific Journal of Marketing and Logistics. 29 (5), 1136-1159

Shahijan, M. K. Rezaei., \& Amin, (2018). Qualities of effective cruise marketing strategy: Cruisers' experience, service convenience, values, satisfaction and revisit intention. International Journal of Quality \& Reliability Management, 35 (10), 2304-2327.

Tanudjaya, P. K. (2014). Pengaruh kualitas pelayanan klinik gigi terhadap kepuasan dan kepercayaan pasien sehingga meningkatkan keinginan untuk berobat kembali. Jurnal Manajemen dan Pemasaran Jasa, 7(1), 39-60.

Tjiptono, F. (2014). Pemasaran Jasa. Yogyakarta: Penerbit Andi.

Utari, W. (2013). Analisis Kualitas Layanan serta Dampaknya terhadap Kepuasan Pasien Rumah Sakit Nasrul Ummah Lamongan. Neo-Bis, 7(1), 89-102.

Wididana, K. B. S. (2017). Analisis pengaruh kualitas pelayanan terhadap kepuasan dan kepercayaan pasien Rumah Sakit Umum Shanti Graha Buleleng. Jurnal Ekonomi \& Bisnis Jagadhita, 3(1), 78-93.

Zubayer M. \& Hoque S. (2019). Health care service quality and in patients' satisfaction: An empirical investigation on healthscape'stangible quality. Global Journal of Arts, Humanities and Social Sciences.

Publisher's Note: SSBFNET stays neutral with regard to jurisdictional claims in published maps and institutional affiliations.

\section{(c) (1)}

(C) 2021 by the authors. Licensee SSBFNET, Istanbul, Turkey. This article is an open access article distributed under the terms and conditions of the Creative Commons Attribution (CC BY) license (http://creativecommons.org/licenses/by/4.0/).

International Journal of Research in Business and Social Science (2147-4478) by SSBFNET is licensed under a Creative Commons Attribution 4.0 International License. 